\title{
Renal neutrophil gelatinase associated lipocalin expression in lipopolysaccharide-induced acute kidney injury in the rat
}

\author{
Mei Han ${ }^{1}$, Ying $\mathrm{Li}^{1 *}$, Maodong Liu', Yingmin $\mathrm{Li}^{2}$ and Bin Cong ${ }^{2}$
}

\begin{abstract}
Background: Neutrophil gelatinase associated lipocalin (NGAL) is a highly predictive biomarker of acute kidney injury. To understand the role of NGAL in renal injury during sepsis, we investigated the temporal changes and biological sources of NGAL in a rat model of acute kidney injury, and explored the relationship between renal inflammation, humoral NGAL and NGAL expression during endotoxemia.

Methods: To induce acute renal injury, rats were treated with lipopolysaccharide (LPS, $3.5 \mathrm{mg} / \mathrm{kg}$, ip), and the location of NGAL mRNA was evaluated by in situ hybridization. Quantitative RT-PCR was also used to determine the dynamic changes in NGAL, tumor necrosis factor a (TNFa) and interleukin (IL)-6 mRNA expression 1, 3, 6, 12, and 24 hours following LPS treatment. The correlation among NGAL, TNFa and IL-6 was analyzed. Urinary and plasma NGAL ( $\mathrm{U} / \mathrm{pNGAL}$ ) levels were measured, and the relationship between humoral NGAL and NGAL expression in the kidney was investigated.

Results: Renal function was affected 3-12 hours after LPS. NGAL mRNA was significantly upregulated in tubular epithelia at the same time $(P<0.001)$. The course of NGAL mRNA upregulation occurred in parallel with renal damage. There was a transient increase in TNFa and IL-6 mRNA levels within 3 hours following LPS administration, and a strong correlation between TNFa and NGAL mRNA $(r=0.995, P<0.001)$ but not with IL-6 mRNA. Both pNGAL and UNGAL levels were markedly increased compared with those in the control group $(P<0.001)$; however, only UNGAL levels were correlated with NGAL mRNA $(r=0.850, P<0.001)$.
\end{abstract}

Conclusions: NGAL upregulation is sensitive to LPS-induced renal TNFa increase and injury, which are observed in the tubular epithelia. Urinary NGAL levels accurately reflect changes in NGAL in the kidney.

Keywords: Neutrophil gelatinase associated lipocalin, lipopolysaccharide, acute kidney injury, tumor necrosis factor a

\section{Background}

Acute kidney injury (AKI; or acute renal failure) is an important issue for patients during critical care, with sepsis being the most common trigger for AKI in the intensive care unit (ICU) [1-3]. Because of the lack of sensitive and specific biomarkers for indicating renal cell injury, the mortality rates for septic AKI have remained high $[1,4]$. Recently, genomic, transcriptomic, and proteomic techniques have identified neutrophil gelatinase associated lipocalin (NGAL) as an early marker of AKI $[5,6]$. NGAL has been investigated in a range of different

\footnotetext{
* Correspondence: yinglihebei@163.com

'Department of Nephropathy, The Third Hospital of Hebei Medical University, Shijiazhuang 050051, China

Full list of author information is available at the end of the article
}

clinical settings, such as contrast-induced nephropathy, AKI after cardiac surgery or kidney transplantation and AKI in the critical care setting. Overall, the sensitivity for NGAL to predict AKI is 0.815 (95\% confidence interval, 0.732-0.892) and it is a promising biomarker for AKI, similar to troponin for acute myocardial infarction [7].

However, the use of NGAL in detecting or predicting the outcomes of patients with septic AKI is complex and depends on the clinical setting. In previous research of critically ill patients $[8,9]$, both serum NGAL (sNGAL) and plasma NGAL (pNGAL) levels have the potential to act as early biomarkers for AKI. While both of them are highly sensitive, they have not been found to be very specific predictors of septic AKI. Shapiro et al. assessed the 
diagnostic accuracy of pNGAL in predicting AKI, wherein it was revealed that pNGAL concentrations of $>150 \mathrm{ng} / \mathrm{mL}$ were $96 \%$ sensitive but only $51 \%$ specific for patients with suspected septic AKI[9]. Martensson et al. observed that pNGAL is elevated in patients with systemic inflammatory response syndrome, severe sepsis, and septic shock, and it should be used with caution as a marker of AKI in ICU patients with septic shock [10]. In contrast, studies have shown that urinary NGAL (uNGAL) is more useful for predicting AKI, as uNGAL levels are not elevated in septic patients without AKI. Understanding the role of NGAL in impaired renal tissues may help clarify this issue.

Furthermore, a biomarker should temporally reflect the pathophysiology initiated by a stimulus leading to injury so as to alert the clinician to a potentially reversible stage of the illness. In the case of septic AKI, the relationship between NGAL and early inflammation mechanisms in the kidney will ought to be clearly established. However, the mechanisms of septic AKI remain undefined. Increasing evidence suggests that intrarenal inflammatory mediators play an important role in the pathogenesis of kidney injury [11-14]. Specially, tumor necrosis factor $\alpha$ (TNF $\alpha)$ is a pivotal proinflammatory mediator and interleukin (IL)-6 is an accessory factor $[15,16]$. However, it remains unknown whether NGAL expression is related to changes in renal IL- 6 and TNF $\alpha$ during the early stage of septic AKI.

Based on the available evidence, the use of NGAL as a marker of septic AKI is promising but requires further investigation. In particular, the relationship between NGAL expression, humoral NGAL and renal inflammation requires additional clarification. However, few studies have specifically investigated the expression of NGAL in renal tissues during sepsis. Therefore, the purpose of this study was to investigate the pattern and localization of renal NGAL expression, and to explore the relationship between renal inflammation mediators, such as TNF $\alpha$ and IL-6, and humoral NGAL in a rat model of lipopolysaccharide (LPS)-induced kidney injury.

\section{Methods}

\section{Animals}

Male Sprague-Dawley rats (Animal Laboratory of Hebei Medical University), 200-220 g, were used in this study. The rats were maintained for a 3-day period before the experimental procedure under a 12-h light/dark cycle at a constant temperature $\left(23 \pm 2^{\circ} \mathrm{C}\right)$, with free access to food and tap water. All animal experiments were in compliance with the guidelines stated by the Institutional Animal Care and Use Committee.

\section{Experimental groups}

Endotoxemia and AKI were induced in the rats by injecting them intraperitoneally (i.p.) with LPS (Escherichia coli 0111: B4, Sigma-Aldrich). The LPS was dissolved in a concentration of $1 \mathrm{mg} / \mathrm{ml}$ in normal saline. Since the response to LPS is strongly dependent on ambient temperature [17], the environmental temperature was maintained at $24^{\circ} \mathrm{C}$.

The rats were randomly assigned into six groups $(n=8$ rats/group). Group 1, the control group, was treated with isometric sterile saline. Groups 2 to 6 were treated with LPS (3.5 mg/kg body weight). Differences between Groups 2 to 6 reflected the different time points following LPS administration at which sampling was conducted $(1,3,6,12$ and $24 \mathrm{~h})$. Urine was gathered via metabolic cages and the supernatant was obtained and collected. The animals were then anaesthetized with sodium pentobarbital (60 mg/kg i.p.), and $2 \mathrm{ml}$ of blood was obtained by cardiac puncture and processed to collect plasma and serum samples, which were frozen at $-80^{\circ} \mathrm{C}$ for subsequent use [18]. The kidneys were also harvested. Half of the kidney was fixed in paraformaldehyde and processed for hematoxylin and eosin $(\mathrm{H} \& \mathrm{E})$ staining and in situ hybridization, and the other half was snap-frozen in liquid nitrogen and stored at $-80^{\circ} \mathrm{C}$ for subsequent biochemical analysis.

\section{Evaluating renal function}

Renal function, in the form of serum creatinine levels, was evaluated in the saline- and LPS-treated animals using a colorimetric assay (Creatinine Assay Kit; Biosino Bio-Technology). The serum creatinine levels were evaluated by measuring the change in absorbance over 40 seconds in the experimental samples relative to the standards.

\section{Histological studies}

Histopathology was conducted on the kidney samples to determine the time-course of renal micro-morphological injury in the LPS-induced endotoxemia rats. Each sample of kidney (one quarter from both the control and experimental groups) was fixed in $4 \%$ paraformaldehyde, dehydrated in graded ethanol and embedded in paraffin as previously described [19]. Each paraffin block was processed into 5 - $\mu$ m-thick slices that were H\&E-stained. A portion $\left(\sim 1 \mathrm{~mm}^{3}\right)$ of renal cortex from each rat was fixed in $2.5 \%$ glutaraldehyde diluted in $0.066 \mathrm{M}$ phosphate buffer ( $\mathrm{pH} 7.4$ ) for 24 hours. The samples were then dehydrated in a graded ethanol series and embedded in Epon 812 resin at $60^{\circ} \mathrm{C}$ for 48 hours. Thin sections $(50 \mathrm{~nm})$ were then double-stained with uranyl acetate and lead citrate, and were observed and photographed with a transmission electron microscope operated at $80 \mathrm{kV}$. The epithelial layer was examined and photographed with a transmission electron microscope (Hitachi, H-7500, TEM) at a magnification of $5000 \times$. 


\section{In situ hybridization}

In situ hybridization was performed on $5-\mu \mathrm{m}$ sections using an acetylcholine receptor in situ hybridization Kit (BioChain Institute, Hayward, CA) with some modifications to the instructions provided by the manufacturers. The following probes were used for whole-mount in situ hybridization: 5'-GCCTGGCAGCGAATGCGGTCC AGAAA GAAAGACAA-3'; 5'-AGGGGCCAGGGCGTG CACTACTGGATCAGAACATT-3', 5'-GACTACGACCA GTTTGCCATGGTATTTTTCCAGGA-3’. Dewaxing, rehydration, and antigen retrieval were performed as previously described [20]. The sections were then incubated in diethyl pyrocarbonate (0.1\% DEPC)-treated PBS and fixed in $4 \%$ paraformaldehyde in PBS for 10 minutes. After being rinsed twice with PBS, the slides were prehybridized with ready-to-use prehybridization solution $(20 \mu \mathrm{l} /$ slice $)$ for 3 hours at $40^{\circ} \mathrm{C}$. The DIG-labeled probe $(0.15 \mu \mathrm{g} / \mu \mathrm{l})$ was diluted to $20 \mathrm{ng} / \mu \mathrm{l}$ in ready-to-use hybridization buffer and applied to the prehybridized tissues. The sections then were incubated at $40^{\circ} \mathrm{C}$ for 16 hours. Posthybridization, the sections were washed and incubated for 2 hours in APconjugated anti-DIG antibodies (1:100, diluted in PBS). After the staining was developed, the reaction was stopped by incubating the slides in $10 \mathrm{mM}$ Tris buffer $(\mathrm{pH} 8.0$, 1 mM EDTA). Finally, the slides were rinsed in distilled $\mathrm{H}_{2} \mathrm{O}$, counterstained with sappan wood, dehydrated with alcohol, transparented with xylene, and then sealed to take images with a dissecting microscope (Olympus, cx31).

\section{RNA extraction and quantitative reverse-transcription polymerase chain reaction (qRT-PCR)}

RNA was extracted from the kidney samples using a single-step RNA isolation method [21] with the Total Quick RNA kit (D9108B; TaKaRa, Dalian, China). The purified RNA (500 ng) was quantified and reverse-transcribed using the PrimeScript RT reagent kit (DRR037A; TaKaRa, Dalian, China), according to the manufacturer's instructions, yielding $20 \mu \mathrm{l}$ of first-strand cDNA. The qRT-PCR experiments were measured on an ABI Prism 7500 RTPCR machine (Applied Biosystems, Carlsbad, CA, USA). The different mRNA expression levels were then calculated and expressed as the number of copies per reaction. All experiments were performed in triplicate. The fold change in mRNA levels of each gene was calculated using the $\triangle \triangle \mathrm{CT}$ method. The mRNA levels were normalized by using GAPDH as a housekeeping gene, and they were compared with the control group. The authenticity and size of the PCR products were confirmed by $2 \%$ agarose gel electrophoresis imprinting. The primers used for amplification are listed in Table 1.

\section{Plasma and urine NGAL concentrations}

Plasma and urine samples were obtained from the rats at $1,3,6,12$, and 24 hours after the LPS (or saline)
Table 1 Primers used for qRT-PCR

\begin{tabular}{lll}
\hline Gene & Sense & Anti-sense \\
\hline TNFa & TACTCCCAGGTTCTCTTCAAGG & GGAGGTTGACTTTCTCCTGGTA \\
\hline IL-6 & TCCTTTGAACTCTACAAGGACC & GTATCCACCATTATGCCCAGCC \\
\hline NGAL & GATGTTGTTATCCTTGAGGCCC & CACTGACTACGACCAGTTTGCC \\
\hline GAPDH & GGCATGGACTGTGGTCATGA & TTCACCACCATGGA GAAGGC \\
\hline
\end{tabular}

Abbreviations: NGAL, neutrophil gelatinase associated lipocalin; TNFa, tumor necrosis factor $a ;$ IL-6, interleukin 6; GAPDH as a housekeeping gene.

treatment, and the concentration of NGAL was determined using a commercially available ELISA kit (CSBE09409r, Cusabio Biotech, China), in accordance with the manufacturer's instructions. Briefly, microtiter plates pre-coated with a goat polyclonal antibody raised against rat NGAL were incubated in blocking buffer containing $1 \%$ $\mathrm{BSA}$, and then coated with $100 \mu \mathrm{L}$ samples of either plasma, urine or NGAL standards (ranging from 1-200 ng/mL). The plates were then incubated with a horseradish peroxidase conjugated, affinity purified rabbit anti-goat IgG antibody, and a TMB substrate was added for color development. The plates were then read within 30 minutes $(450 \mathrm{~nm})$ with a Benchmark Plus microplate reader (BioTek Instruments Inc., Winooski, VT, USA). All measurements were performed in triplicate.

\section{Statistical analysis}

All values are expressed as mean \pm SEM. The data were normally distributed, as determined using a KolmogorovSmirnov test. Comparisons among groups were conducted with one-way ANOVA. When the F value was significant $(P<0.05)$, the Student-Newman-Keuls Test and least significant difference procedure were performed to test for differences between the means. We used simple regression analysis after log transformation to evaluate whether the values were correlated. A $P$ value of less than 0.05 was considered to be significant.

\section{Results}

\section{LPS-induced AKI}

Rats treated with LPS showed significantly elevated levels of serum creatinine, which were significantly increased from 3 to 12 hours after LPS administration compared with those in the control group $(P<0.001$, Figure $1 \mathrm{~A})$.

Histopathology was also performed to determine the time-course of renal damage following LPS treatment. The kidneys from the control group showed normal glomeruli and tubules. In contrast, the kidneys of the LPS-treated rats were characterized by transient renal damage. Under a light microscope, there were no intrinsic lesions within the glomeruli, but lesions consisting of epithelial swelling were observed in the 3-12-hour groups. Further, intracellular edema was also detected and was more severe in the straight segment of the 


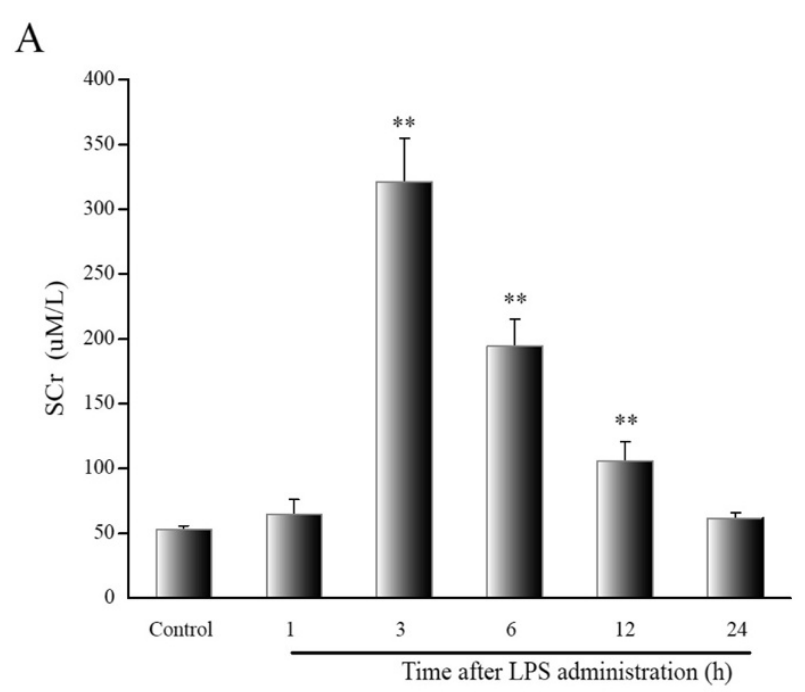

B

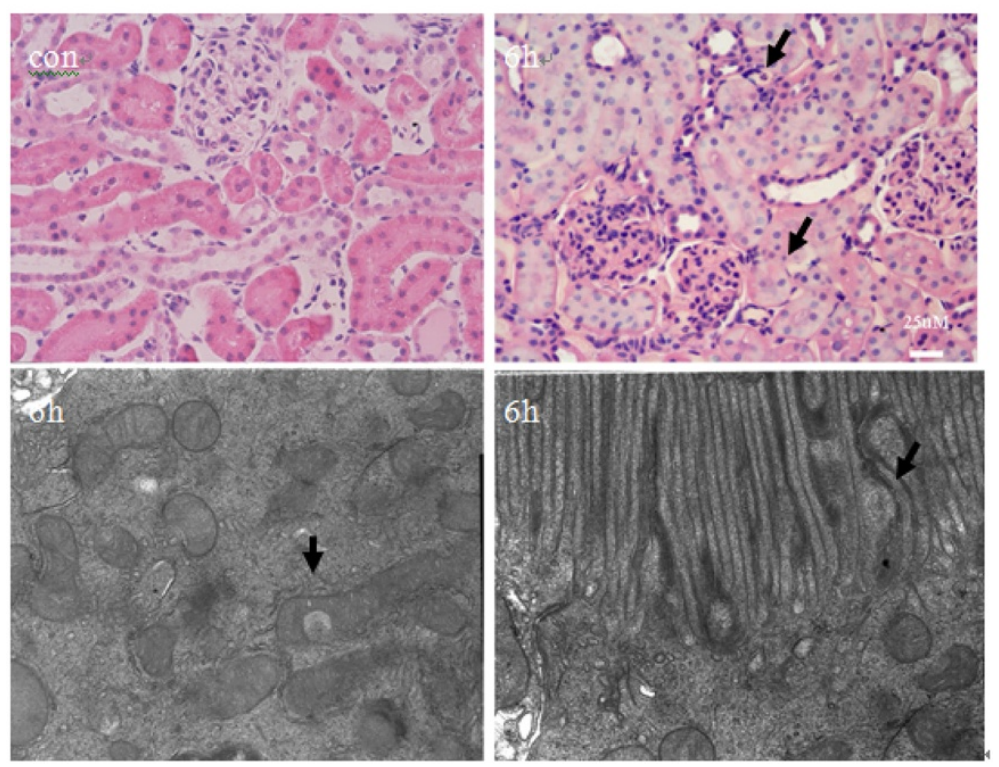

Figure $1 \mathrm{SCr}$ and renal histological injury in rats subjected to LPS at different time points. A, SCr levels are shown, with the mean values/ group obtained by colorimetric assay (UM/L). There was a significant increase in $\mathrm{SCr}$ levels in rats at 3, 6 and 12 hours. B, Renal histology under light microscopy and TEM at 6 hours following LPS treatment (H\&E, 200x; TEM, 5000x) are shown. The arrows indicate intracellular edema, inflammatory cell infiltration, microvilli in disarray, or injury to the mitochondrial outer membrane. Abbreviations: $\mathrm{SCr}=$ serum creatinine. **P $<0.001$, relative to the control group.

proximal tubules in the LPS-treated rats. Ultrapathology analysis further demonstrated the presence of intracellular edema, coupled with disarranged microvilli, and/or injury or destruction of the mitochondrial outer membrane in the proximal epithelia (Figure 1B).

On the basis of changes to serum creatinine levels and renal histology, we were able to confirm LPS-induced $\mathrm{AKI}$, and thus confirm that we had established a suitable animal model.

\section{Upregulation of NGAL gene expression in the tubular epithelia}

Using in situ hybridization analysis, we observed weak NGAL mRNA expression in the distal tubular epithelia and medullary collecting ducts of the control kidneys; however, NGAL mRNA expression was not detected by qRT-PCR. In contrast, 24.3-49.6\% of the tubular cells, including the proximal epithelia, were NGAL mRNA positive in the kidneys of Groups 2 to 5 (1, 3, 6 and 12 
hours post-LPS treatment, respectively), whereas NGAL mRNA expression was significantly decreased in the kidneys from Group 6 (24 hours post-LPS treatment) (Figure 2A). This finding was also confirmed by qRT-PCR, where LPS-treatment induced the upregulation of renal NGAL mRNA from 3 to 12 hours following treatment compared with controls $(P<0.001)$. More specifically, at its peak, the expression of NGAL mRNA increased by 260-fold (Group 4, 6 hours post LPS), and decreased to 23-fold the normal expression levels in Group 6, 24 hours after LPS-treatment (Figure 2B). The PCR products of NGAL were confirmed by $2 \%$ agarose gel electrophoresis imprinting (Figure $2 \mathrm{C}$ ). These results are similar to previously published data from a patient study [22].

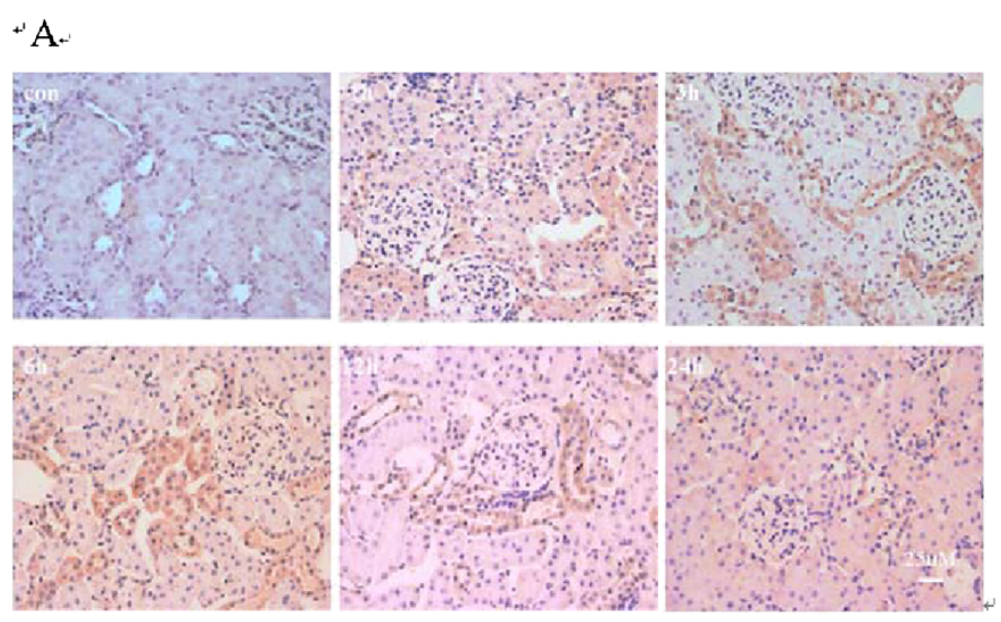

B

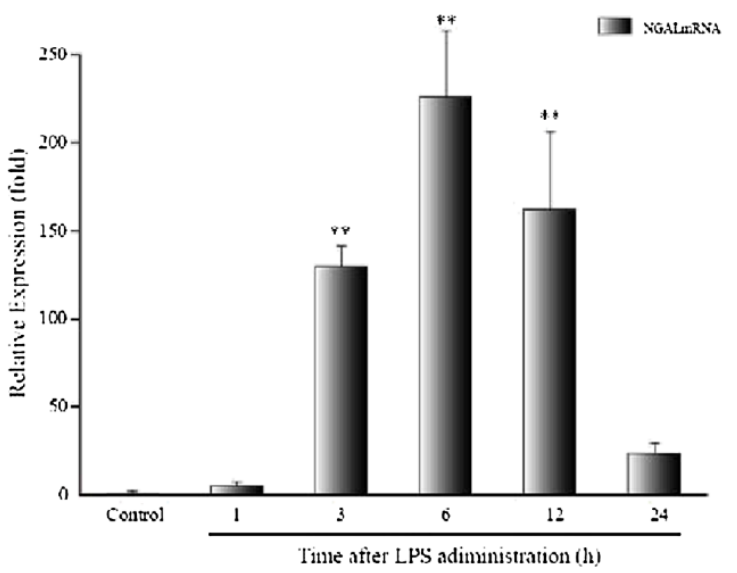

$\mathrm{C}$

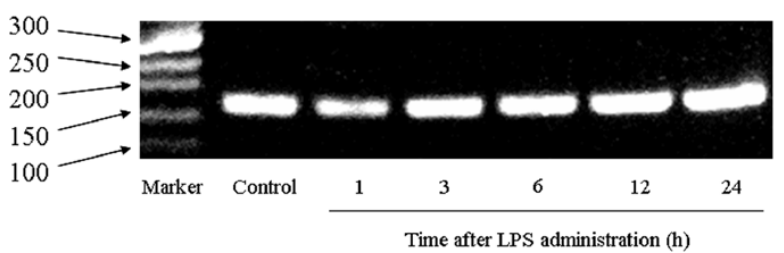

Figure 2 Expression of NGAL mRNA in the LPS-treated rats. A, In situ hybridization signal time-course. A strong hybridization signal was observed in the cortical tubular epithelia in samples in the 3-, 6- and 12-hour LPS groups compared with a weak signal in the 1-and 24-hour LPS groups, and there was no signal in the controls. B, Relative expression of NGAL mRNA (relative to the controls) is shown. C, Agarose gel electrophoresis imprinting expresses the intensity of NGAL mRNA in the LPS-treated rats. There was a 129-fold increase in NGAL mRNA expression at 3 hours after LPS treatment, rising to 226 -fold at 6 hours and then it decreased to 162 -fold at 12 hours. ${ }^{* *} P<0.001$, relative to the control group. 


\section{Urinary NGAL levels corresponded to NGAL mRNA expression}

Plasma and urinary NGAL levels increased soon after LPS administration. Compared with the control group, pNGAL levels were markedly increased in experimental groups and still persisted at high levels in Group 6 (24 hours after administration) $(P<0.001)$, by which time the renal damage had disappeared. Peak pNGAL levels $(192.68 \pm 14.37 \mathrm{ng} / \mathrm{ml})$ were obtained by 3 -hour post-LPS treatment (Group 3, Figure 3A).

With regard to $\mathrm{UNGAL}$, the LPS-treated rats showed anuria at the early stages following LPS-treatment. However, uNGAL levels increased from 3 to 12 hours (Groups 3, 4 and 5, P<0.001), and they then decreased to normal levels in Group 6, 24 hours after LPS-treatment $(P=0.194)$. Peak uNGAL values $(154.42 \pm 12.75 \mathrm{ng} / \mathrm{ml})$ were observed at the 6 -hour time point (Group 4). The

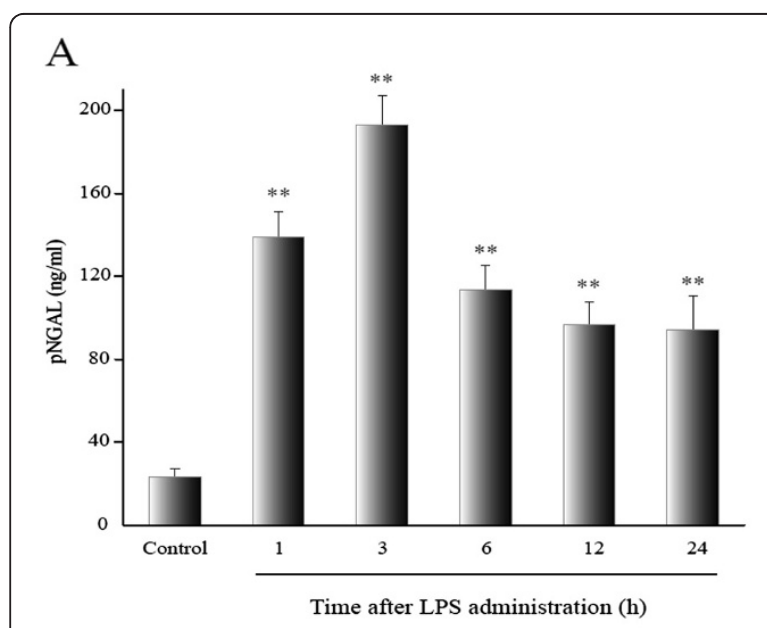

$\mathrm{B}$

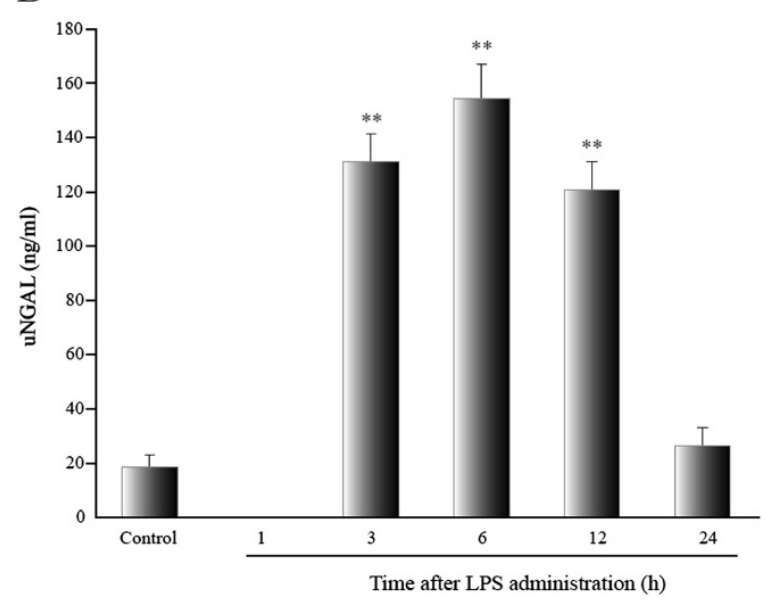

Figure 3 Plasma and urinary NGAL levels in the rats subjected to LPS-treatment. Data represent the mean \pm SEM of five experiments. Abbreviations: $\mathrm{pNGAL}=$ plasma $\mathrm{NGAL} ; \mathrm{UNGAL}=$ urinary NGAL. ${ }^{* *} P<0.001$, relative to the control group. trends observed for UNGAL levels were similar to the results of NGAL qRT-PCR analysis, and there was a correlation between the two $(\mathrm{r}=0.850, P<0.001)$. The correlation between pNGAL and NGAL mRNA in the injured kidney was not significant (Table 2, Figure 3B).

\section{TNFa and NGAL mRNA are strongly correlated}

There was an obvious inflammatory reaction in the kidneys following LPS treatment. Both TNF $\alpha$ and IL-6 mRNA expression were significantly increased at the early stage of LPS-induced AKI $(P<0.001)$. Specifically, TNF $\alpha$ mRNA increased by 24-fold in the first hour (Group 2) and then decreased to baseline levels 3 hours after treatment (Group 4). Similarly, expression of IL-6 mRNA also increased 24-fold in the first hour (Group 2), but the expression of IL-6 continued to increase to 68-fold greater than baseline levels at 3 hours post-treatment (Group 3), and then decreased to baseline levels at 6 hours (Group 4). There was a strong correlation between TNF $\alpha$ and NGAL mRNAs $(\mathrm{r}=0.995, \mathrm{P}<0.001)$, but IL-6 mRNA was not correlated with NGAL mRNA (Table 2, Figure 4).

\section{Discussion}

Almost half of all septic patients develop AKI [23]. Despite advances in treatment strategies for these patients, mortality due to septic AKI in critically ill patients remains high, with a mortality rate up to $60 \%$ [3]. Of those patients that survive, 5-20\% will require dialysis [24]. The poor clinical outcome of septic AKI patients partly reflects the lack of knowledge regarding the pathophysiology of septic AKI. In addition, early diagnosis of septic AKI with markers of renal function, such as serum creatinine, which would allow for initiation treatment regimens before the disease process before becoming irreversible, are currently inadequate. In response to these difficulties, there has been a concerted effort to use high-throughput technologies such as proteomics to identify novel early biomarkers of AKI. The identification and study of NGAL marks an important step forward to identify these biomarkers [25,26]. Human NGAL was originally identified in neutrophils as a $25 \mathrm{kDa}$ protein

Table 2 Correlation between renal inflammatory factors, humoral NGAL levels and NGAL mRNA in LPS-induced AKI rats

\begin{tabular}{lll}
\hline & NGAL mRNA & \\
\cline { 2 - 3 } & $\mathbf{r}$ & $\boldsymbol{p}$ \\
\hline TNFa mRNA & 0.995 & $P<0.001$ \\
\hline IL-6 mRNA & 0.276 & $P=0.653$ \\
\hline UNGAL & 0.850 & $P<0.001$ \\
\hline PNGAL & 0.328 & $P>0.05$ \\
\hline
\end{tabular}

Abbreviations: NGAL, neutrophil gelatinase associated lipocalin; TNFa, tumor necrosis factor $a$; IL-6, interleukin 6; uNGAL, urinary NGAL; pNGAL, plasma NGAL. 


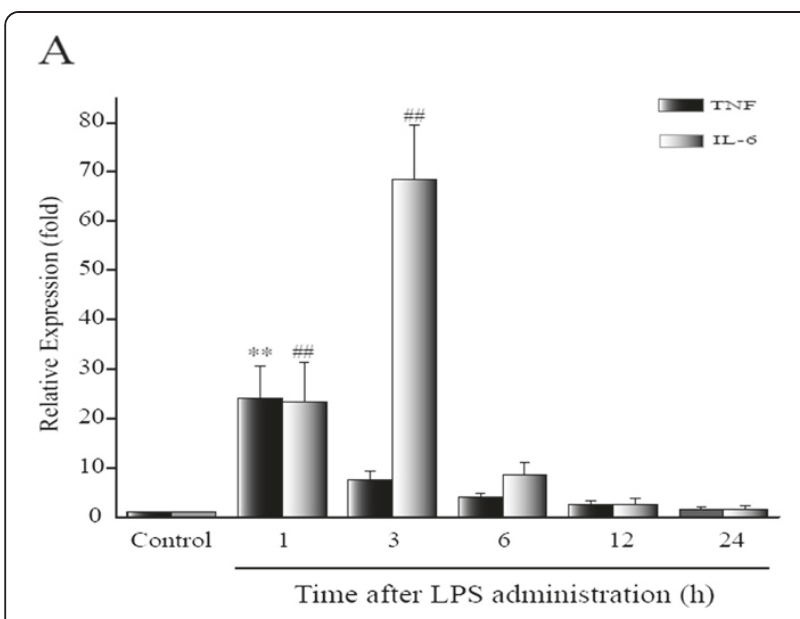

B

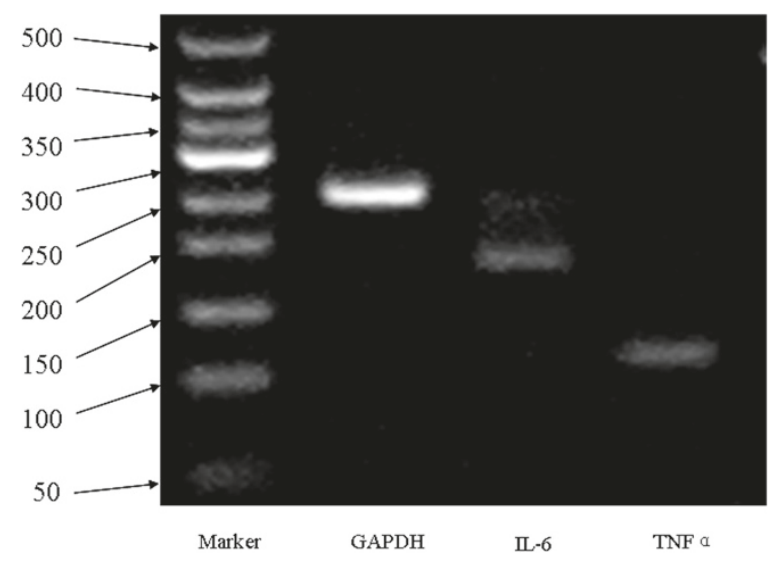

Figure 4 Expression of TNFa mRNA and IL- 6 mRNA in the LPStreated rats. A, Relative expression of TNFa and IL- 6 mRNA. LPS treatment induced upregulation of TNFa and IL-6 mRNA levels, increasing the expression of both mRNAs by 24 -fold at 1 hour following LPS-treatment, and IL-6 expression rose by 68 -fold at 3 hours post-treatment. B, Agarose gel electrophoresis imprinting for TNFa and IL-6 mRNA at 1 hour after LPS administration. ${ }^{* *} P<0.001$, relative to the TNFa control group; ${ }^{\# \#} P<0.001$, relative to the IL-6 control group.

covalently bound to matrix metalloproteinase-9 (MMP9) [27]. Importantly, NGAL fulfills many of the characteristics of a suitable "real-time" renal biomarker. For instance, it has been suggested that serum/urine NGAL levels, in addition to the intensity of NGAL staining, may serve as an early biomarker for renal injury following kidney transplantation [28-31]. Further, NGAL gene is also significantly up-regulated in the kidney following an ischemic insult [5] and has been demonstrated to be a highly predictive biomarker of other acute and chronic kidney injuries [32-36].

There are several studies that have analyzed the diagnostic and predictive properties of serum, plasma and urine NGAL in newborn [37] and adult patients critically ill with septic AKI $[10,38,39]$. Despite the interest in NGAL, particularly as a biomarker, there is much uncertainty and divergence regarding its use within the literature. There are several possible explanations for these differences. First, NGAL is a member of the lipocalin superfamily. This is consistent with the role of NGAL as an endogenous bacteriostatic protein that scavenges bacterial siderophores [40]. Therefore, NGAL is significantly increased in bacterial infections compared with viral infections $[41,42]$. Furthermore, increased sNGAL levels have been reported during systemic disease in the absence of overt bacterial infection, most notably during the acute-phase response [43], inflammation [10,44-46], hypertension [47] and chronic disease $[48,49]$, as well as during renal tubular injury. It should be noted that patients with sepsis typically present with co-morbidities. Because NGAL levels may be influenced by these other conditions, the adoption of NGAL as a biomarker of septic AKI must be tempered with caution.

There is limited knowledge of the dynamic changes in NGAL expression during renal injury, especially in the case of sepsis-induced renal injury. Therefore, there are many questions that still need to be answered. One question is "Where is the cellular source of NGAL in the damaged kidney"? In a study by Mori et al. [22], weak NGAL staining was observed in approximately $10 \%$ of the total cortical area of the distal tubules, and in the medullary collecting ducts of the normal kidneys from healthy volunteers. In contrast, the proximal tubules did not express NGAL. However, in ischemic or nephrotoxindamaged kidneys from patients, nearly $50 \%$ of the cortical tubules, including the proximal tubules, expressed NGAL. In a mouse models of renal ischemia-reperfusion injury, Mishra and colleagues verified that the NGAL protein is expressed predominantly in the proliferating cell nuclear antigen-positive proximal tubule cells within 3 hours of ischemia [5]. For the first time, we detected NGAL gene expression in 24.3-49.6\% cortical tubular epithelia, including proximal epithelia, from 1 to 12 hours following LPS administration, which is similar to the findings by Mori and Mishra. However, in the study of Paragas et al. [50], they found that NGAL mRNA was not expressed by epithelia in proximal tubules in the rat at 24 hours after treatment with lipid A (15 mg/kg, i.p.), but the medullary cells demonstrated intensive NGAL mRNA expression. These data described above suggest the following. 1) Different parts of the kidney have different responses to factors causing injury, including endotoxin, but overall, the injured epithelia are the source of NGAL. 2) Epithelia in proximal tubules might be sensitive to endotoxin, and they can upregulate the NGAL gene even though the LPS concentration is low, but the reactive period is short. Thus, NGAL expression can be detected in the early stage after LPS administration, and then decrease to baseline levels. 
4) The cells in the medullary tubules might be insensitive, and they will not become active until they face a high concentration of LPS. However, they can increase NGAL expression longer than the cells in proximal tubules.

Moreover, the relationship between NGAL in renal injury and humoral NGAL needs to be clarified. Paragas and colleagues [45] verified that UNGAL originates in the kidney from results of cross-transplants between NGAL knockout and wild-type mice, followed by renal artery clamping. They found that NGAL is present in the kidney, liver, spleen, lung and trachea after lipid A treatment, which indicates that NGAL in the blood is not a good marker of septic AKI [50]. Our study revealed, for the first time, the pattern of renal NGAL expression during the early stage of endotoxemia. We found that renal NGAL could be a useful biomarker of renal epithelia injury. In particular, uNGAL exactly reflected the change in renal NGAL expression, whereas pNGAL was not as accurate in septic AKI. Therefore, based on the findings of these studies, it appears that UNGAL levels are related to NGAL gene expression in the kidney, and uNGAL has the ability to act as a marker for the diagnosis and monitoring of AKI in patients with sepsis. This could lead to renoprotective therapies and avoidance of renal injury. However, pNGAL or sNGAL levels may be misleading in the diagnosis of septic AKI. Misdiagnosis may result in conservative strategies and the optimal therapeutic time in critically ill patients may be missed.

Sepsis is associated with the production of many inflammatory mediators, including TNF $\alpha[51,52]$. TNF $\alpha$ is released first when sepsis occurs and leads to cleavage of the nuclear factor $\kappa \mathrm{B}(\mathrm{NF}-\mathrm{\kappa B})$ inhibitor. Once this inhibitor is removed, NF- $\mathrm{B}$ is able to initiate the production of mRNA, which induces the production of other proinflammatory cytokines, chemokines, and adhesion molecules [53]. For instance, Knotek et al. demonstrated that TNF $\alpha$ is a critical mediator of endotoxin-induced sepsis, and that TNF $\alpha$ inhibition prevents physiological changes and morbidities associated with LPS administration in wild-type and inducible nitric oxide synthase knockout mice [54]. Therefore, TNF $\alpha$ is a key mediator of LPSinduced acute renal failure, acting through its receptor, TNFR1 [55]. Early changes in renal TNF $\alpha$ mRNA levels after endotoxemia have not been reported. In our study, we found that TNF $\alpha$ mRNA was induced by 24-fold within 3 hours after LPS treatment. The result of our study also confirm the findings of Wang and colleagues, they showed that LPS induced TNF- $\alpha$ protein by 24-fold in the kidney 16 hours after administration[14]. Furthermore, for the first time, we showed that NGAL mRNA was related to TNF $\alpha$ mRNA levels in the injured kidney, and that NGAL mRNA upregulation closely followed TNF $\alpha$ mRNA increase, similar to a down-regulation cytokine in the inflammation cascade. Previous studies
$[22,50]$ have found that NGAL is suppressed by the NF$\mathrm{\kappa B}$ inhibitor in primary kidney cells after lipid A administration, and that the NGAL:siderophore:Fe complex preserves proximal tubule $\mathrm{N}$-cadherin and inhibits cell death. Therefore, is it possible that TNF $\alpha / N F-\kappa B / N G A L$ is an important mechanism for regulating tubular cells by increasing proliferation and/or inducing/suppressing apoptosis during sepsis? This possibility should be investigated in future studies.

\section{Conclusions}

The upregulation of NGAL gene expression in the tubular epithelia occurs after LPS-treatment, and this finding is coupled with the observation of renal TNF $\alpha$ increase and injury. Urinary NGAL levels accurately reflect the changes in NGAL mRNA in this kidney injury model.

\section{Competing interests}

The authors have no competing interests to declare.

\section{Author details}

${ }^{1}$ Department of Nephropathy, The Third Hospital of Hebei Medical University, Shijiazhuang 050051, China. ${ }^{2}$ Department of Forensic Medicine, Hebei Medical University, Shijiazhuang 050051, China.

\section{Authors' contributions}

$\mathrm{MH}$ collected samples, performed the histology and in situ hybridization analysis, performed the GRT-PCR and ELISA, and wrote and edited the manuscript. $Y L$ coordinated the in vivo studies and edited the manuscript. $M D L$ coordinated the in vitro studies and edited the manuscript. YML and BC edited the manuscript. All authors read and approved the final manuscript.

Received: 4 January 2012 Accepted: 7 May 2012

Published: 7 May 2012

\section{References}

1. Uchino S, Kellum JA, Bellomo R, Doig GS, Morimatsu H, Morgera S, Schetz M, Tan I, Bouman C, Macedo E, et al: Acute renal failure in critically ill patients: a multinational, multicenter study. Jama 2005, 294(7):813-818.

2. Medve L, Antek C, Paloczi B, Kocsi S, Gartner B, Marjanek Z, Bencsik G, Kanizsai $P$, Gondos T: Epidemiology of acute kidney injury in Hungarian intensive care units: a multicenter, prospective, observational study. BMC Nephrol, 12:43.

3. Parmar A, Langenberg C, Wan L, May CN, Bellomo R, Bagshaw SM: Epidemiology of septic acute kidney injury. Curr Drug Targets 2009, 10 (12):1169-1178.

4. Matejovic M, Chvojka J, Radej J, Ledvinova L, Karvunidis T, Krouzecky A, Novak I: Sepsis and acute kidney injury are bidirectional. Contrib Nephrol, 174:78-88.

5. Mishra J, Ma Q, Prada A, Mitsnefes M, Zahedi K, Yang J, Barasch J, Devarajan $P$ : Identification of neutrophil gelatinase-associated lipocalin as a novel early urinary biomarker for ischemic renal injury. J Am Soc Nephrol 2003, 14(10):2534-2543.

6. Supavekin S, Zhang W, Kucherlapati R, Kaskel FJ, Moore LC, Devarajan P: Differential gene expression following early renal ischemia/reperfusion. Kidney Int 2003, 63(5):1714-1724.

7. Haase M, Bellomo R, Devarajan P, Schlattmann P, Haase-Fielitz A: Accuracy of neutrophil gelatinase-associated lipocalin (NGAL) in diagnosis and prognosis in acute kidney injury: a systematic review and meta-analysis. Am J Kidney Dis 2009, 54(6):1012-1024.

8. Wheeler DS, Devarajan P, Ma Q, Harmon K, Monaco M, Cvijanovich N, Wong HR: Serum neutrophil gelatinase-associated lipocalin (NGAL) as a marker of acute kidney injury in critically ill children with septic shock. Crit Care Med 2008, 36(4):1297-1303.

9. Shapiro NI, Trzeciak S, Hollander JE, Birkhahn R, Otero R, Osborn TM, Moretti E, Nguyen HB, Gunnerson K, Milzman D, et al: The diagnostic accuracy of 
plasma neutrophil gelatinase-associated lipocalin in the prediction of acute kidney injury in emergency department patients with suspected sepsis. Ann Emerg Med, 56(1):52-59. e51.

10. Martensson J, Bell M, Oldner A, Xu S, Venge P, Martling CR: Neutrophil gelatinase-associated lipocalin in adult septic patients with and without acute kidney injury. Intensive Care Med, 36(8):1333-1340.

11. Ramesh G, Zhang B, Uematsu S, Akira S, Reeves WB: Endotoxin and cisplatin synergistically induce renal dysfunction and cytokine production in mice. Am J Physiol Renal Physiol 2007, 293(1):F325-332.

12. Zager RA, Johnson AC, Geballe A: Gentamicin suppresses endotoxindriven TNF-alpha production in human and mouse proximal tubule cells. Am J Physiol Renal Physiol 2007, 293(4):F1373-1380.

13. Zager RA, Johnson AC, Lund S: Uremia impacts renal inflammatory cytokine gene expression in the setting of experimental acute kidney injury. Am J Physiol Renal Physiol 2009, 297:(4)F961-970.

14. Wang W, Bansal S, Falk S, Ljubanovic D, Schrier R: Ghrelin protects mice against endotoxemia-induced acute kidney injury. Am J Physiol Renal Physiol 2009, 297(4):F1032-1037

15. Ramesh G, Kimball SR, Jefferson LS, Reeves WB: Endotoxin and cisplatin synergistically stimulate TNF-alpha production by renal epithelial cells. Am J Physiol Renal Physiol 2007, 292(2):F812-819.

16. Grigoryev DN, Liu M, Hassoun HT, Cheadle C, Barnes KC, Rabb H: The local and systemic inflammatory transcriptome after acute kidney injury. J Am Soc Nephrol 2008, 19(3):547-558.

17. Romanovsky AA, Ivanov Al, Shimansky YP: Selected contribution: ambient temperature for experiments in rats: a new method for determining the zone of thermal neutrality. J Appl Physiol 2002, 92(6):2667-2679.

18. Foglieni C, Fulgenzi A, Ticozzi P, Pellegatta F, Sciorati C, Belloni D, Ferrero E, Ferrero ME: Protective effect of EDTA preadministration on renal ischemia. BMC Nephrol 2006, 7:5.

19. Racusen LC: Alterations in tubular epithelial cell adhesion and mechanisms of acute renal failure. Lab Invest 1992, 67(2):158-165.

20. Phillips TM: Measurement of total and bioactive interleukin-2 in tissue samples by immunoaffinity-receptor affinity chromatography. Biomed Chromatogr 1997, 11(4):200-204.

21. Chomczynski P, Sacchi N: The single-step method of RNA isolation by acid guanidinium thiocyanate-phenol-chloroform extraction: twentysomething years on. Nat Protoc 2006, 1(2):581-585.

22. Mori K, Lee HT, Rapoport D, Drexler IR, Foster K, Yang J, Schmidt-Ott KM, Chen X, Li JY, Weiss S, et al: Endocytic delivery of lipocalin-siderophoreiron complex rescues the kidney from ischemia-reperfusion injury. J Clin Invest 2005, 115(3):610-621.

23. Wan L, Bagshaw SM, Langenberg C, Saotome T, May C, Bellomo R: Pathophysiology of septic acute kidney injury: what do we really know? Crit Care Med 2008, 36(4 Suppl):S198-203.

24. Hoste EA, Schurgers M: Epidemiology of acute kidney injury: how big is the problem? Crit Care Med 2008, 36(4 Suppl):S146-151.

25. Urbschat A, Obermuller N, Haferkamp A: Biomarkers of kidney injury. Biomarkers, 16(1):22-30

26. Nguyen MT, Devarajan P: Biomarkers for the early detection of acute kidney injury. Pediatr Nephrol 2008, 23(12):2151-2157.

27. Mishra J, Mori K, Ma Q, Kelly C, Yang J, Mitsnefes M, Barasch J, Devarajan P: Amelioration of ischemic acute renal injury by neutrophil gelatinaseassociated lipocalin. J Am Soc Nephrol 2004, 15(12):3073-3082.

28. Mishra J, Ma Q, Kelly C, Mitsnefes M, Mori K, Barasch J, Devarajan P: Kidney NGAL is a novel early marker of acute injury following transplantation. Pediatr Nephrol 2006, 21(6):856-863.

29. Hall IE, Yarlagadda SG, Coca SG, Wang Z, Doshi M, Devarajan P, Han WK, Marcus RJ, Parikh CR: IL-18 and urinary NGAL predict dialysis and graft recovery after kidney transplantation. J Am Soc Nephrol, 21(1): 189-197.

30. Malyszko J, Malyszko JS, Mysliwiec M: Serum neutrophil gelatinaseassociated lipocalin correlates with kidney function in renal allograft recipients. Clin Transplant 2009, 23(5):681-686.

31. Bataille A, Abbas S, Semoun O, Bourgeois E, Marie O, Bonnet F, RescheRigon M, Abboud I, Losser MR, Jacob L: Plasma neutrophil gelatinaseassociated lipocalin in kidney transplantation and early renal function prediction. Transplantation, 92(9):1024-1030

32. Fu WJ, Li BL, Wang SB, Chen ML, Deng RT, Ye CQ, Liu L, Fang AJ, Xiong SL, Wen $S$, et al: Changes of the tubular markers in type 2 diabetes mellitus with glomerular hyperfiltration. Diabetes Res Clin Pract, :
33. Haase M, Haase-Fielitz A: [Acute kidney injury after cardiac surgery: Early diagnosis with neutrophil gelatinase-associated lipocalin]. Med Klin (Munich), 116(2):111-116

34. Perrin C, Patard JJ, Jouan F, Collet N, Theoleyre S, Edeline J, Zerrouki S, Laguerre B, Bellaud-Roturaud MA, Rioux-Leclercq N, et al: [The neutrophil gelatinase-associated lipocalin, or LCN 2, marker of aggressiveness in clear cell renal cell carcinoma]. Prog Urol, 21(12):851-858.

35. Atzori L, Mussap M, Noto A, Barberini L, Puddu M, Coni E, Murgia F, Lussu M, Fanos V: Clinical metabolomics and urinary NGAL for the early prediction of chronic kidney disease in healthy adults born ELBW. J Matern Fetal Neonatal Med, 24(2):41-44.

36. Gaspari F, Cravedi P, Mandala M, Perico N, de Leon FR, Stucchi N, Ferrari S, Labianca R, Remuzzi G, Ruggenenti P: Predicting cisplatin-induced acute kidney injury by urinary neutrophil gelatinase-associated lipocalin excretion: a pilot prospective case-control study. Nephron Clin Pract, 115 (2):154-160.

37. Mussap M, Noto A, Fravega M, Fanos V: Urine neutrophil gelatinaseassociated lipocalin (UNGAL) and netrin-1: are they effectively improving the clinical management of sepsis-induced acute kidney injury (AKI)? J Matern Fetal Neonatal Med, 24(2):16-18.

38. Bagshaw SM, Haase M, Haase-Fielitz A, Bennett M, Devarajan P, Bellomo R: A prospective evaluation of urine microscopy in septic and non-septic acute kidney injury. Nephrol Dial Transplant, :

39. Bagshaw SM, Bennett M, Haase M, Haase-Fielitz A, Egi M, Morimatsu H D'Amico G, Goldsmith D, Devarajan P, Bellomo R: Plasma and urine neutrophil gelatinase-associated lipocalin in septic versus non-septic acute kidney injury in critical illness. Intensive Care Med, 36(3):452-461.

40. Goetz DH, Holmes MA, Borregaard N, Bluhm ME, Raymond KN, Strong RK: The neutrophil lipocalin NGAL is a bacteriostatic agent that interferes with siderophore-mediated iron acquisition. Mol Cell 2002, 10(5): 1033-1043.

41. Fjaertoft $G$, Foucard $T, X u S$, Venge P: Human neutrophil lipocalin (HNL) as a diagnostic tool in children with acute infections: a study of the kinetics. Acta Paediatr 2005, 94(6):661-666.

42. Bjorkqvist M, Kallman J, Fjaertoft G, Xu S, Venge P, Schollin J: Human neutrophil lipocalin: normal levels and use as a marker for invasive infection in the newborn. Acta Paediatr 2004, 93(4):534-539.

43. Liu Q, Nilsen-Hamilton M: Identification of a new acute phase protein. J Biol Chem 1995, 270(38):22565-22570.

44. Tadesse S, Luo G, Park JS, Kim BJ, Snegovskikh W, Zheng T, Hodgson EJ, Arcuri F, Toti P, Parikh CR, et al: Intra-amniotic infection upregulates neutrophil gelatinase-associated lipocalin (NGAL) expression at the maternal-fetal interface at term: implications for infection-related preterm birth. Reprod Sci, 18(8):713-722.

45. Zerega B, Cermelli S, Michelis B, Cancedda R, Cancedda FD: Expression of NRL/NGAL (neu-related lipocalin/neutrophil gelatinase-associated lipocalin) during mammalian embryonic development and in inflammation. Eur J Cell Biol 2000, 79(3):165-172.

46. Nielsen BS, Borregaard N, Bundgaard JR, Timshel S, Sehested M, Kjeldsen L: Induction of NGAL synthesis in epithelial cells of human colorectal neoplasia and inflammatory bowel diseases. Gut 1996, 38(3):414-420.

47. Leoncini G, Mussap M, Viazzi F, Fravega M, Degrandi R, Bezante GP, Deferrari $G$, Pontremoli R: Combined use of urinary neutrophil gelatinaseassociated lipocalin (UNGAL) and albumin as markers of early cardiac damage in primary hypertension. Clin Chim Acta, 412(21-22):1951-1956.

48. Fassett RG, Robertson IK, Ball MJ, Geraghty DP, Cardinal JW, Coombes JS: Effects of atorvastatin on NGAL and cystatin C in chronic kidney disease: a post hoc analysis of the LORD trial. Nephrol Dial Transplant, :

49. Bolignano D, Lacquaniti A, Coppolino G, Campo S, Arena A, Buemi M: Neutrophil gelatinase-associated lipocalin reflects the severity of renal impairment in subjects affected by chronic kidney disease. Kidney Blood Press Res 2008, 31(4):255-258.

50. Paragas N, Qiu A, Zhang Q, Samstein B, Deng SX, Schmidt-Ott KM, Viltard M, Yu W, Forster CS, Gong G, et al: The Ngal reporter mouse detects the response of the kidney to injury in real time. Nat Med, 17(2):216-222.

51. Tracey KJ: Tumor necrosis factor (cachectin) in the biology of septic shock syndrome. Circ Shock 1991, 35(2):123-128.

52. Molloy RG, Mannick JA, Rodrick ML: Cytokines, sepsis and immunomodulation. Br J Surg 1993, 80(3):289-297.

53. Wu X, Guo R, Chen P, Wang Q, Cunningham PN: TNF induces caspasedependent inflammation in renal endothelial cells through a Rho- and 
myosin light chain kinase-dependent mechanism. Am J Physiol Renal Physiol 2009, 297(2):F316-326.

54. Knotek M, Rogachev B, Wang W, Ecder T, Melnikov V, Gengaro PE, Esson M Edelstein CL, Dinarello CA, Schrier RW: Endotoxemic renal failure in mice: Role of tumor necrosis factor independent of inducible nitric oxide synthase. Kidney Int 2001, 59(6):2243-2249.

55. Cunningham PN, Dyanov HM, Park P, Wang J, Newell KA, Quigg RJ: Acute renal failure in endotoxemia is caused by TNF acting directly on TNF receptor-1 in kidney. J Immunol 2002, 168(11):5817-5823.

doi:10.1186/1471-2369-13-25

Cite this article as: Han et al:: Renal neutrophil gelatinase associated

lipocalin expression in lipopolysaccharide-induced acute kidney injury in the rat. BMC Nephrology 2012 13:25.

\section{Submit your next manuscript to BioMed Central and take full advantage of:}

- Convenient online submission

- Thorough peer review

- No space constraints or color figure charges

- Immediate publication on acceptance

- Inclusion in PubMed, CAS, Scopus and Google Scholar

- Research which is freely available for redistribution 